\title{
B7-H3 promoted proliferation of mouse spermatogonial stem cells via the PI3K signaling pathway
}

\author{
Xuedong Wei ${ }^{1, *}$, Kai Li ${ }^{1,2, *}$, Guangbo Zhang ${ }^{3}$, Yuhua Huang ${ }^{1}$, Jinxing Lv ${ }^{1}$, Miao Li ${ }^{1}$, \\ Lun Zhao ${ }^{1}$, Caibin Fan' ${ }^{2}$, Jinxian $\mathrm{Pu}^{1}$, Jianquan Hou ${ }^{1}$ and Hexing Yuan ${ }^{1}$ \\ ${ }^{1}$ Department of Urology, First Affiliated Hospital of Soochow University, Suzhou, Jiangsu, People's Republic of China \\ 2 Department of Urology, Suzhou Municipal Hospital, Suzhou, Jiangsu, People's Republic of China \\ ${ }^{3}$ Department of Clinical Immunology Laboratory, First Affiliated Hospital of Soochow University, Suzhou, Jiangsu, People's \\ Republic of China \\ * These authors have contributed equally to this work \\ Correspondence to: Hexing Yuan, email: YHXurology@163.com \\ Jianquan Hou, email: xf192@163.com
}

Keywords: B7-H3; testis; mouse spermatogonial stem cell; proliferation; PI3K pathway; Immunology

Received: May 18, $2017 \quad$ Accepted: December 06, $2017 \quad$ Published: December 20, 2017

Copyright: Wei et al. This is an open-access article distributed under the terms of the Creative Commons Attribution License 3.0 (CC BY 3.0), which permits unrestricted use, distribution, and reproduction in any medium, provided the original author and source are credited.

\section{ABSTRACT}

Objective: We found seminal B7-H3 was associated with human sperm concentration. However, the mechanism is unclear. The purpose of this study was to investigate the expression of B7-H3 in mouse testis and determine the effects of B7H3 on the proliferation of mouse spermatogonial stem cells (SSCs) and the underlying mechanisms.

Methods: B7-H3 expression in the testis of mice at different ages ( 3 weeks, 8 weeks, 4 months and 9 months) was detected by western blot and immunohistochemistry. CCK-8 were used to measure mouse SSCs proliferation after incubation with different concentrations of B7-H3 for 1-72 h in vitro. Flow cytometry was used to analyze the cell cycle of mouse SSCs after incubation with different concentrations of B7-H3 for 48 and $72 \mathrm{~h}$. The signaling pathways involved were assessed by western blot.

Results: Four-month-old mice had the highest expression of $\mathrm{B} 7-\mathrm{H} 3$ in the testis, while 3-week-old mice had the lowest expression of B7-H3. B7-H3 was predominantly detected on the membrane and in the cytoplasm of Sertoli cells. Furthermore, B7-H3 promoted mouse SSCs proliferation and increased the percentage of cells in S+G2/M phase in a time- and dose-dependent manner in vitro. These effects were inhibited by LY294002, indicating the involvement of the phosphoinositide 3-kinase signaling pathway.

Conclusions: The expression of B7-H3 in mouse testis, especially Sertoli cells, was associated with mouse age. In vitro, B7-H3 promoted the proliferation and accelerated the cell cycle of mouse SSCs via the PI3K pathway, indicating a critical role of B7-H3 expressed by Sertoli cells in mouse spermatogenesis.

\section{INTRODUCTION}

Spermatogenesis is a continuous, productive and strictly controlled process $[1,2]$ that is supported by the self-renewal and differentiation of spermatogonial stem cells (SSCs) in the microenvironment of the seminiferous tubules [3]. Sertoli cells, the only somatic cell type in the tubules, control the proliferation and differentiation of SSCs by direct interaction and secretion of specific factors [4].
B7-H3, a type I transmembrane protein, was initially described as a new member of the B7 family in 2001 [5]. There is a soluble form of this protein, which can be released into the circulation [6]. We previously reported that soluble B7-H3 was detected in expressed prostatic secretions [7]. To date, the $\mathrm{B} 7-\mathrm{H} 3$ protein has been detected in multiple organs, including the liver, testis, and epididymis [8]. However, there is no consensus on the biological functions of $\mathrm{B} 7-\mathrm{H} 3$. The original study reported that $\mathrm{B} 7-\mathrm{H} 3$ could activate $\mathrm{T}$ cells and increase $\mathrm{T}$ cell 
proliferation as well as interferon- $\gamma$ (IFN- $\gamma$ ) production [5]. In contrast, several subsequent studies found that B7H3 inhibited T cell function [9-12]. Other reports have examined the non-immunological role of B7-H3. Sun et al. [13] found that B7-H3 inhibited tumor growth by decreasing the expression of vascular endothelial growth factor (VEGF). B7-H3 also promoted the differentiation of human marrow stromal cells to osteoblasts [14]. Our previous study identified an association between seminal B7-H3 with sperm concentrations and progressive motility and also showed that B7-H3 promoted human sperm motility in vitro [15]. Thus, B7-H3 may have a critical role in normal spermatogenesis. However, the underlying mechanisms and the biological functions of B7-H3 in this process are still unknown.

Extracellular signal-Regulated Kinases (ERK), c-Jun N-terminal kinase (JNK) and Phosphoinositide 3-Kinases (PI3Ks) are the three most intensively studied signaling pathways that participate in spermatogenesis [16-19]. PI3Ks are ubiquitous lipid kinases that serve as signal molecules downstream of receptors on the cell surface $[20,21]$. To date, the PI3K signaling pathway has been shown to play a role in male fertility and spermatogonia proliferation. Feng et al. [22] reported that stem cell factor $(\mathrm{SCF}) / \mathrm{C}$-kit promoted proliferation of type A spermatogonia by recruiting PI3K/AKT/p70 S6 kinase $(p 70 S 6 K) /$ cyclin D3. Sagare-Patil et al. [23] found that progesterone regulated motility and hyperactivation of human sperm via the PI3K-AKT pathway. Moreover, glial cell line-derived neurotrophic factor (GDNF) utilizes the rat sarcoma (Ras)/ERK1/2 pathway to promote SSC proliferation [24]. MAPK/ERK kinase (MEK)/ERK signaling contributes to periodic self-renewal/proliferation of SSCs [25]. Hydrogen peroxide induced reactive oxygen species (ROS) via activation of the p38 mitogen-activated protein kinase (MAPK) and JNK pathways to enhance self-renewal of SSCs [26]. The JNK1/2 pathway may play an important role in regulating sperm viability [27].

Based on these reports and our previous studies mentioned above, we examined (1) whether B7-H3 expression in mouse testis is dependent on age or gonad maturation; (2) whether $\mathrm{B} 7-\mathrm{H} 3$ regulates the proliferation and cell cycle of mouse SSCs; and (3) which signaling pathways are involved in this process.

\section{RESULTS}

\section{Localization of B7-H3 in mouse testis}

To examine B7-H3 in the different phases in mouse sexual maturity, as described by Flurkey et al. [28], we selected four groups of mice: 3 -w-old mice, 8 -w-old

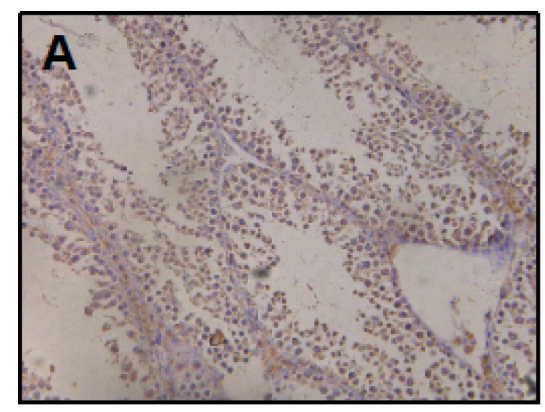

3W

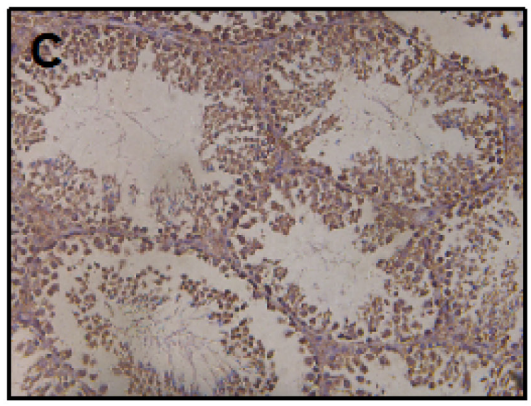

$4 \mathrm{M}$

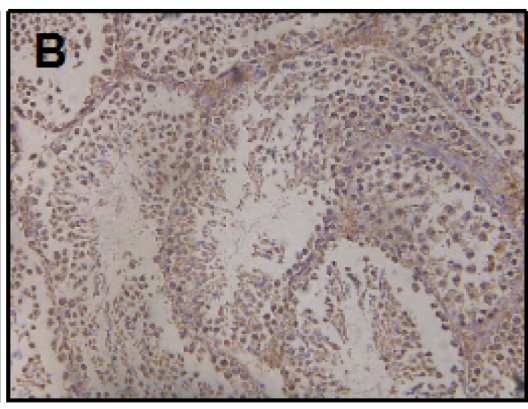

8W

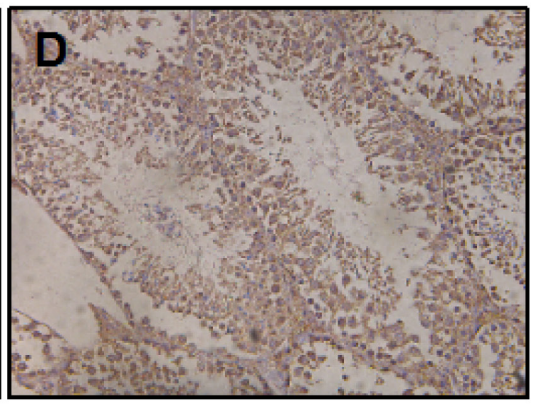

9M

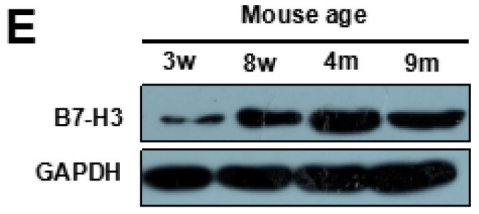

$\mathbf{F}$



Figure 1: The expression of B7-H3 in mouse testis at different ages. A. to D. Representative images of mouse testis tissues stained with B7-H3. Magnification, X200. E. The collected mouse testes from different ages were digested and lysed, and the precleared tissue lysates were assessed by western blot using an anti-B7-H3 antibody. GAPDH was used as the loading control. F. The graph represents the quantification of B7-H3 abundance shown in $(E)$ normalized to the corresponding GAPDH in three independent experiments. The results are expressed as the mean \pm standard deviation $(n=3)$. Differences were analyzed by one-way ANOVA followed by Tukey's post hoc analysis. ${ }^{*} P<0.01, * * * P<0.001$ and $* * * * P<0.0001$. 
mice, 4 m-old mice and 9-m-old mice, which represented juvenile, adolescent, mature and middle aged mice. As shown in Figure 1A to 1D, compared to the sexually immature mice, the sexually mature mice had increased amounts of sperm in the seminiferous tubules. B7-H3 staining was positive both on the membrane and in the cytoplasm of mouse testis tissues from all stages. The testes from the $4 \mathrm{~m}$ mice had the strongest B7-H3 staining compared with the staining of those from other ages.

\section{The expression of $\mathrm{B} 7-\mathrm{H3}$ in mouse testes at different stages}

The highest expression of B7-H3 was observed in the testes of the $4 \mathrm{~m}$ mice (all $P<0.01$ ), which were sexually mature. The expression levels of B7-H3 in the mouse testes of the $3 \mathrm{w}, 8 \mathrm{w}$ and $9 \mathrm{~m}$ groups were $22.76 \% \pm 1.31 \%, 64.40 \% \pm 6.25 \%$ and $65.36 \% \pm 4.20 \%$, respectively, compared to those of the $4 \mathrm{~m}$ mice (Figure 1E and $1 \mathrm{~F}$ ). These data also demonstrated that the expression of B7-H3 in testis was increased during the process of maturation to an adult, after which it decreased.

\section{B7-H3 promotes mouse SSC proliferation and cell cycle progression}

Mouse SSCs were used to investigate the effects of $\mathrm{B} 7-\mathrm{H} 3$ on spermatogenesis. Figure 2A shows representative flow cytometry data of C-kit and Oct-4, markers for SSCs [29-31], and expression on mouse SSCs (Figure 2A).

To investigate the role of $\mathrm{B} 7-\mathrm{H} 3$ in mouse SSC growth, we analyzed the proliferation rate of the cells using CCK-8 assays in vitro. Mouse SSCs were incubated with different concentrations of B7-H3 $(0,5,10,25 \mathrm{ng} /$ $\mathrm{mL}$ ) for various time points $(1,6,12,24,48,72 \mathrm{~h})$. As shown in Figure 2B, regardless of the concentration of $\mathrm{B} 7-\mathrm{H} 3$, from 1 to $48 \mathrm{~h}$, the proliferation rate of SSCs increased; however, from 48 to $72 \mathrm{~h}$, the proliferation rate of SSCs decreased. After $48 \mathrm{~h}$ of incubation, the proliferation rates of SSCs treated with $10 \mathrm{ng} / \mathrm{ml}$ (OD value, $1.25 \pm 0.04$ ) and $25 \mathrm{ng} / \mathrm{ml}(\mathrm{OD}$ value, $1.21 \pm 0.06$ ) B7-H3 were both significantly higher than those of SSCs treated with $0 \mathrm{ng} / \mathrm{ml}$ (OD value, $1.08 \pm 0.02$ ) and $5 \mathrm{ng} / \mathrm{ml}$ (OD value, $1.07 \pm 0.06$ ) B7-H3 (all $P<0.001$ ). However, the differences in cell proliferation between the $0 \mathrm{ng} / \mathrm{ml}$ and $5 \mathrm{ng} / \mathrm{ml} \mathrm{B7-H3-treated} \mathrm{groups} \mathrm{were} \mathrm{not} \mathrm{statistically}$

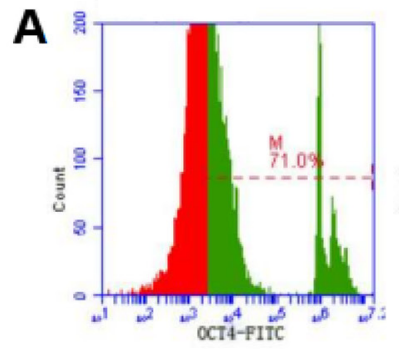

B

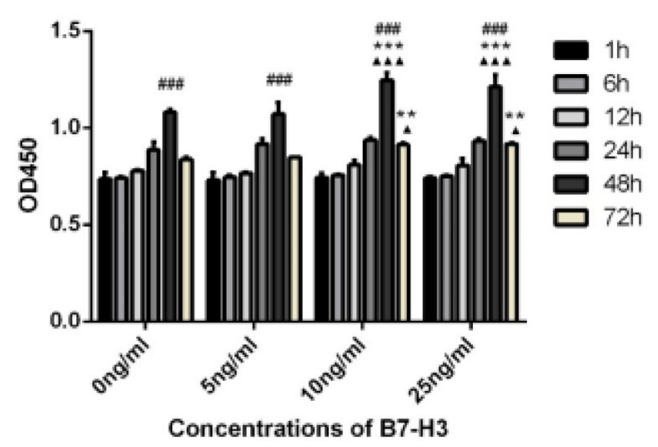

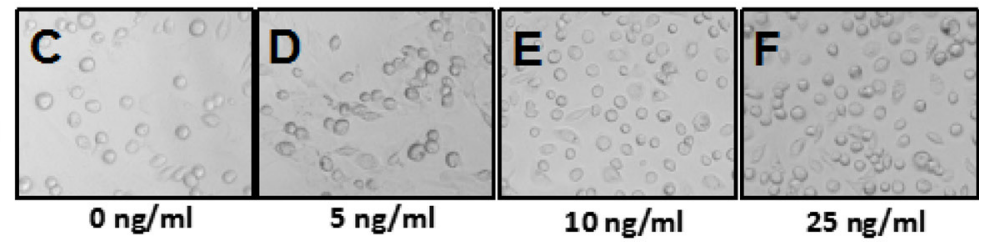

G

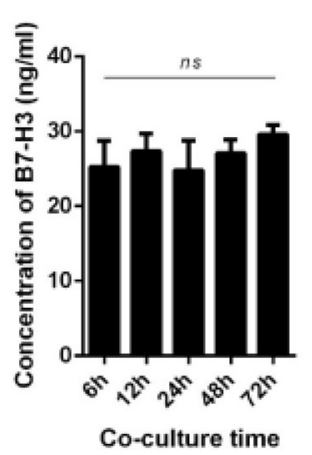

H

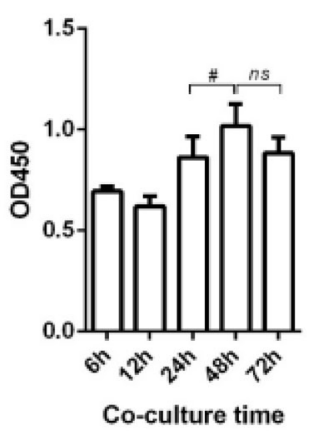

Figure 2: The effect of B7-H3 on mouse SSC proliferation. A. The expression of C-kit and Oct-4 on mouse SSCs was analyzed by flow cytometry. B. Mouse SSCs were incubated with different concentrations of B7-H3 (0, 5, 10, $25 \mathrm{ng} / \mathrm{mL})$ for various time points $(1$, $6,12,24,48,72 \mathrm{~h}$ ) in vitro. Then, cells were collected for proliferation assessment using CCK8 assays. The results are expressed as the mean \pm standard deviation $(n=3)$. Differences were analyzed by two-way ANOVA followed by Tukey's post hoc analysis. \#\#\#P $<0.001$ versus 24 h. ${ }^{*} * P<0.01, * * * P<0.001$ versus $0 \mathrm{ng} / \mathrm{ml}$. $\boldsymbol{\Delta} P<0.05, \boldsymbol{\Delta} \boldsymbol{\Delta} \boldsymbol{\Delta} P<0.0001$ versus $5 \mathrm{ng} / \mathrm{ml}$. C. to F. Representative images of SSCs incubated with different concentrations of B7-H3 at $48 \mathrm{~h}$. G. The SSCs were co-cultured with TM4 for 6 to $72 \mathrm{~h}$ in vitro, and the supernatants were collected at each time point for B7-H3 evaluation. The data were analyzed by repeated measures one-way ANOVA. H. The co-cultured SSCs in $(G)$ were harvested and assessed for proliferation as described in $(B)$. Data were analyzed by repeated measures one-way ANOVA with Tukey's post tests. $\# P<0.05$ versus $24 \mathrm{~h}$. 
significant $(P>0.05)$. Moreover, there was no difference in cell proliferation between SSCs treated with $10 \mathrm{ng} / \mathrm{ml}$ and $25 \mathrm{ng} / \mathrm{ml} \mathrm{B} 7-\mathrm{H} 3(P>0.05)$.

Similarly, after $72 \mathrm{~h}$ of incubation, cell proliferation in the $10 \mathrm{ng} / \mathrm{ml}$ (OD value, $0.91 \pm 0.01$ ) and $25 \mathrm{ng} / \mathrm{ml}$ (OD value, $0.92 \pm 0.01$ ) B7-H3-treated groups was higher than that in the groups treated with $0 \mathrm{ng} / \mathrm{ml}$ (OD value, $0.84 \pm 0.01$ ) and $5 \mathrm{ng} / \mathrm{ml}$ (OD value, $0.85 \pm 0.00) \mathrm{B} 7-\mathrm{H} 3$ (all $P<0.05$ ). Furthermore, the differences between the $10 \mathrm{ng} / \mathrm{ml}$ and $25 \mathrm{ng} / \mathrm{ml} \mathrm{B} 7-\mathrm{H} 3$-treated groups were not statistically significant $(P>0.05)$. These results indicated that $\mathrm{B} 7-\mathrm{H} 3$ promotes SSC proliferation in a time- and dose-dependent manner.

Additionally, the cell cycle was evaluated by using BrdU incorporation after mouse SSCs were incubated with different concentrations of B7-H3 for 48 and 72 h. As shown in Figure 3B, after $48 \mathrm{~h}$ of incubation, the percentage of SSCs in $\mathrm{S}+\mathrm{G} 2 / \mathrm{M}$ phase was significantly higher in the $10 \mathrm{ng} / \mathrm{ml}(89.20 \% \pm 2.07 \%)$ and $25 \mathrm{ng} / \mathrm{ml}$ $(89.00 \% \pm 1.61 \%) \mathrm{B} 7-\mathrm{H} 3$-treated groups than that in the groups treated with $0 \mathrm{ng} / \mathrm{ml}(72.77 \% \pm 1.53 \%)$ and $5 \mathrm{ng} /$ $\mathrm{ml}(77.43 \% \pm 4.01 \%) \mathrm{B} 7-\mathrm{H} 3$ (all $P<0.001)$. However, the differences between the $10 \mathrm{ng} / \mathrm{ml}$ and $25 \mathrm{ng} / \mathrm{ml} \mathrm{B} 7-\mathrm{H} 3-$ treated SSCs were not statistically significant $(P>0.05)$. After $72 \mathrm{~h}$ of incubation, only the $10 \mathrm{ng} / \mathrm{ml} \mathrm{B} 7-\mathrm{H} 3$-treated SSCs had a higher $\mathrm{S}+\mathrm{G} 2 / \mathrm{M}$ percentage compared to that of cells treated with $0 \mathrm{ng} / \mathrm{ml} \mathrm{B} 7-\mathrm{H} 3(P<0.05)$.

Since B7-H3 was predominantly expressed on mouse Sertoli cells but not on SSCs (Supplementary Figure
1), we co-cultured these two cell types and investigated if the Sertoli cell-derived B7-H3 affects the proliferation of SSCs. As shown in Figure 2G, the concentrations of B7H3 in co-culture supernatants at $6,12,24,48$, and $72 \mathrm{~h}$ were $25.30 \pm 3.45,27.35 \pm 2.30,24.82 \pm 3.96,27.07 \pm 1.82$ and $29.62 \pm 1.27 \mathrm{ng} / \mathrm{ml}$, respectively, which were higher than those used in the current study. However, no significant difference was found between these time points $(P>$ $0.05)$. The SSCs co-cultured with TM4 for $48 \mathrm{~h}$ had a higher proliferation rate than those co-cultured for $24 \mathrm{~h}$ $(P<0.05)$, consistent with the data from $\mathrm{B} 7-\mathrm{H} 3$ protein stimulation. However, there was no difference between the 48 and $72 \mathrm{~h}$ co-cultures $(P>0.05)$ (Figure $2 \mathrm{H})$. Co-culture with TM4 promoted the cell cycle of SSCs at both $48 \mathrm{~h}$ and $72 \mathrm{~h}(P<0.05)$, although the difference between these two time points was not significant $(P>0.05)$ (Figure 3C).

\section{B7-H3 activates the PI3K pathway in mouse SSCs}

As shown in Figure 4A, mouse SSCs were treated with $10 \mathrm{ng} / \mathrm{ml} \mathrm{B} 7-\mathrm{H} 3$ at various time points $(0,15,30,60$ $\mathrm{min}$ ), and the lysates were analyzed by western blotting. The results indicated that B7-H3 substantially increased the phosphorylation of PI3K (P-PI3K) at 30 min compared to that at other time points (all $P<0.0001$, Figure 4A and 4B). ERK and JNK, the other two commonly studied signaling pathways involved in regulating SSC proliferation, were also evaluated. However, there were no significant changes in the phosphorylation of ERK1/2
A
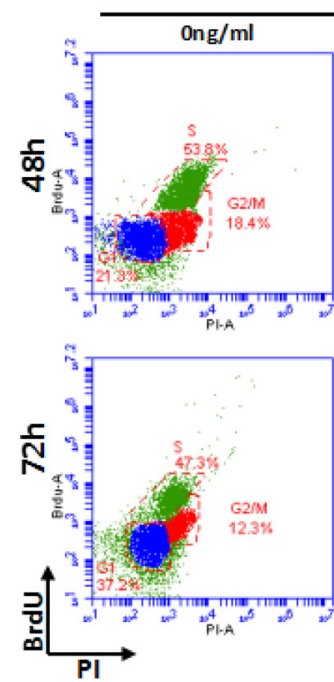

B7-H3

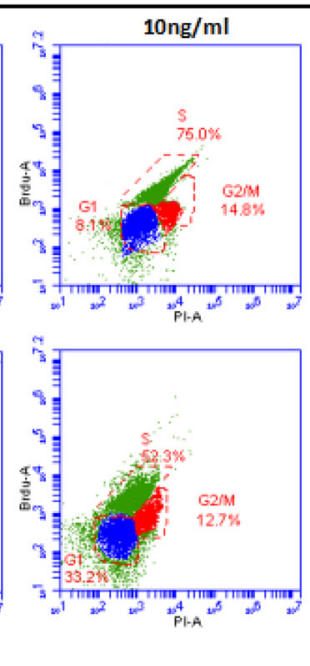

B

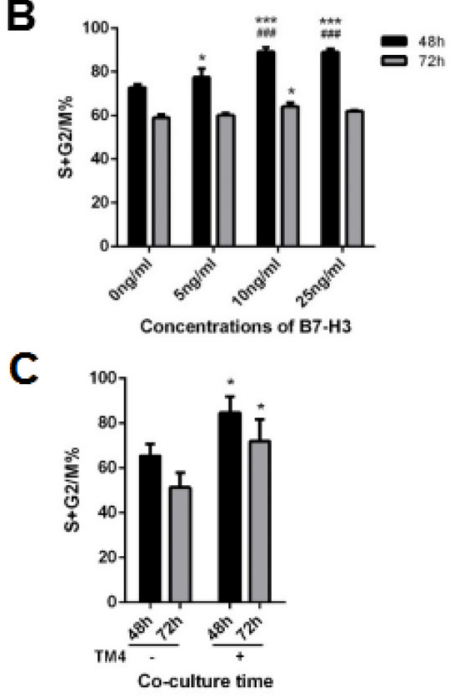

Figure 3: The effect of B7-H3 on the cell cycle of mouse SSCs. A. Mouse SSCs were incubated with different concentrations of B7-H3 $(0,5,10,25 \mathrm{ng} / \mathrm{mL})$ for 48 and $72 \mathrm{~h}$ in vitro, and the cell cycle was assessed by BrdU incorporation. Representative flow cytometry data from three independent experiments are shown. B. The graph represents the percentage of cells in $\mathrm{S}+\mathrm{G} 2 / \mathrm{M}$ shown in $(A)$ in three independent experiments. The results are expressed as the mean \pm standard deviation $(n=3)$. Differences were analyzed by two-way ANOVA followed by Tukey's post hoc analysis. ${ }^{*} P<0.05$, ${ }^{* * *} P<0.001$ versus $0 \mathrm{ng} / \mathrm{ml}$. \#\#\#P<0.001 versus $5 \mathrm{ng} / \mathrm{ml}$. C. The SSCs were co-cultured with or without TM4 for 48 or $72 \mathrm{~h}$ and collected for cell cycle analysis. Data were analyzed by two-way ANOVA, followed by Tukey's post hoc analysis. $* P<0.05$ versus non-co-cultured cells. 

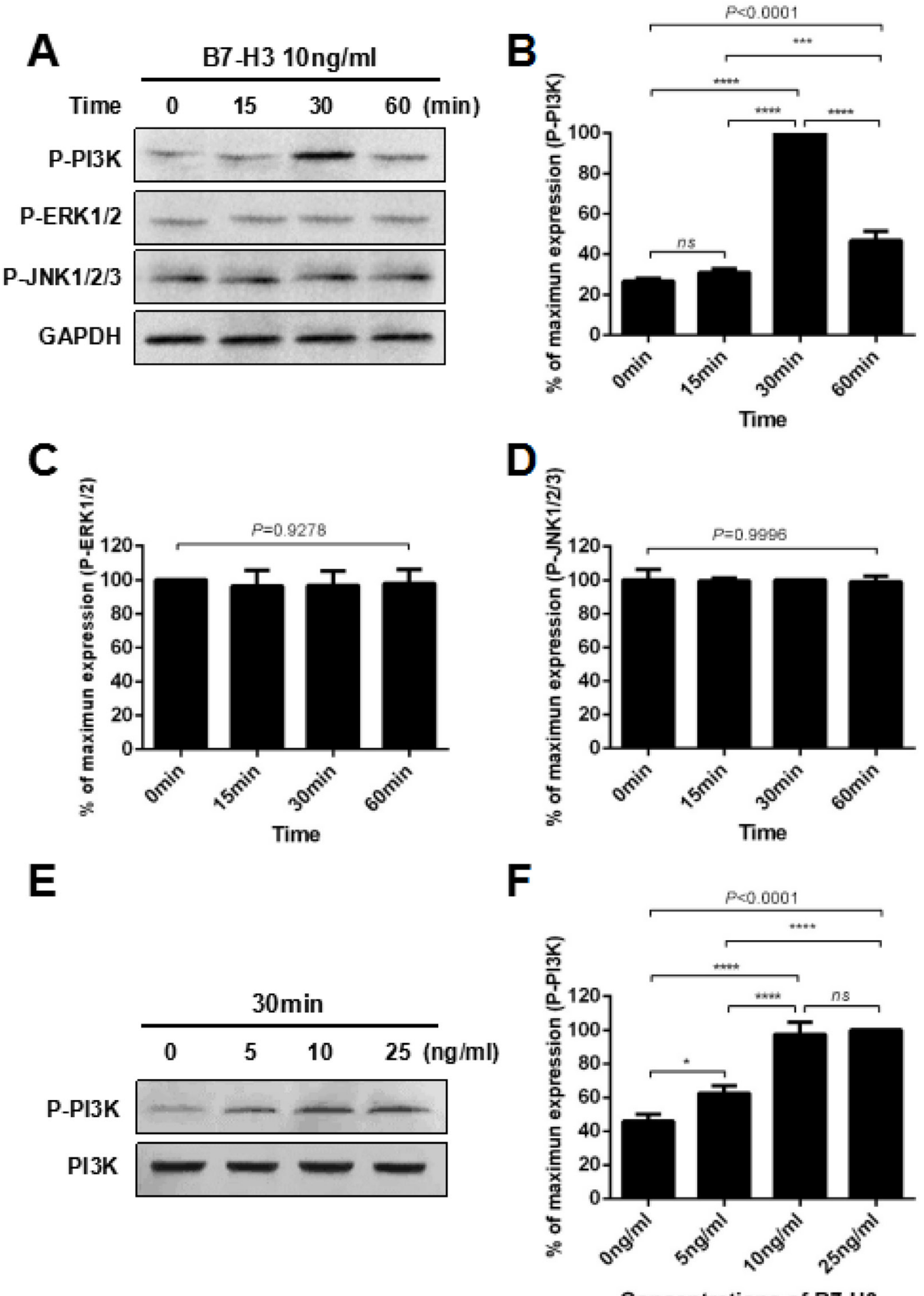

Concentrations of $\mathrm{B} 7-\mathrm{H} 3$

Figure 4: B7-H3 activated the PI3K signaling pathway in mouse SSCs. A. Mouse SSCs were incubated with $10 \mathrm{ng} / \mathrm{ml}$ B7$\mathrm{H} 3$ for $0,15,30$ and 60 min in vitro, and cell lysates were assessed by western blot using anti-phospho-PI3K, anti-phospho-ERK1/2 and anti-phospho-JNK1/2/3 antibodies. GAPDH was used as a loading control. B. to D. Graphs represent the quantification of phosphorylation of PI3K, ERK1/2 and JNK1/2/3 shown in $(A)$, respectively, which was normalized to the corresponding GAPDH in three independent experiments. E. Mouse SSCs were incubated with different concentrations of B7-H3 $(0,5,10,25 \mathrm{ng} / \mathrm{ml})$ for $30 \mathrm{~min}$ in vitro, and cell lysates were assessed by western blotting using an anti-phospho-PI3K antibody. PI3K was used as the loading control. F. The graph represents the quantification of phosphorylation of PI3K shown in $(E)$, which was normalized to the corresponding PI3K in three independent experiments. The results are expressed as the mean \pm standard deviation $(n=3)$. Differences were analyzed by one-way ANOVA followed by Tukey's post hoc analysis. ${ }^{*} P<0.05,{ }^{* * *} P<0.001,{ }^{* * * *} P<0.0001$. 
$(\mathrm{P}-\mathrm{ERK} 1 / 2)(P=0.9278)$ and JNK1/2/3 (P-JNK1/2/3) $(P$ $=0.9996)$ after treatment with B7-H3 for different times.

To further explore the effect of B7-H3 on phosphorylation of PI3K in mouse SSCs, we incubated the cells with different concentrations of B7-H3 $(0,5$, 10, $25 \mathrm{ng} / \mathrm{ml}$ ) for $30 \mathrm{~min}$. As shown in Figure 4E and $4 \mathrm{~F}$, the $25 \mathrm{ng} / \mathrm{ml} \mathrm{B7-H3-treated} \mathrm{SSCs} \mathrm{had} \mathrm{the} \mathrm{highest}$ phosphorylation of PI3K. However, the difference was not statistically significant compared to that of the $10 \mathrm{ng} /$ ml B7-H3-treated SSCs $(P>0.05)$. Nevertheless, both of these two groups had higher phosphorylation of PI3K than that of cells treated with $0 \mathrm{ng} / \mathrm{ml}$ and $5 \mathrm{ng} / \mathrm{ml} \mathrm{B} 7-\mathrm{H} 3$ (all $P<0.0001)$

\section{A PI3K inhibitor blocks the progression of the cell cycle of SSCs induced by B7-H3}

To further confirm the role of the PI3K pathway in the B7-H3-induced cell cycle progression of mouse SSCs, we pretreated the SSCs with $10 \mu \mathrm{M}$ LY294002, a widely used PI3K inhibitor, prior to incubation with $10 \mathrm{ng} / \mathrm{ml} \mathrm{B} 7$ $\mathrm{H} 3$ for $48 \mathrm{~h}$ and $72 \mathrm{~h}$.

After $48 \mathrm{~h}$ of incubation, the percentage of $\mathrm{S}+\mathrm{G} 2 / \mathrm{M}$ cells in the $10 \mathrm{ng} / \mathrm{ml} \mathrm{B7-H3-treated} \mathrm{SSCs}$ $(85.77 \% \pm 4.69 \%)$ was significantly increased compared to that in SSCs without B7-H3 treatment $(72.13 \% \pm 3.33 \%)(P$ $<0.05)$, while the $\mathrm{S}+\mathrm{G} 2 / \mathrm{M}$ percentage was significantly

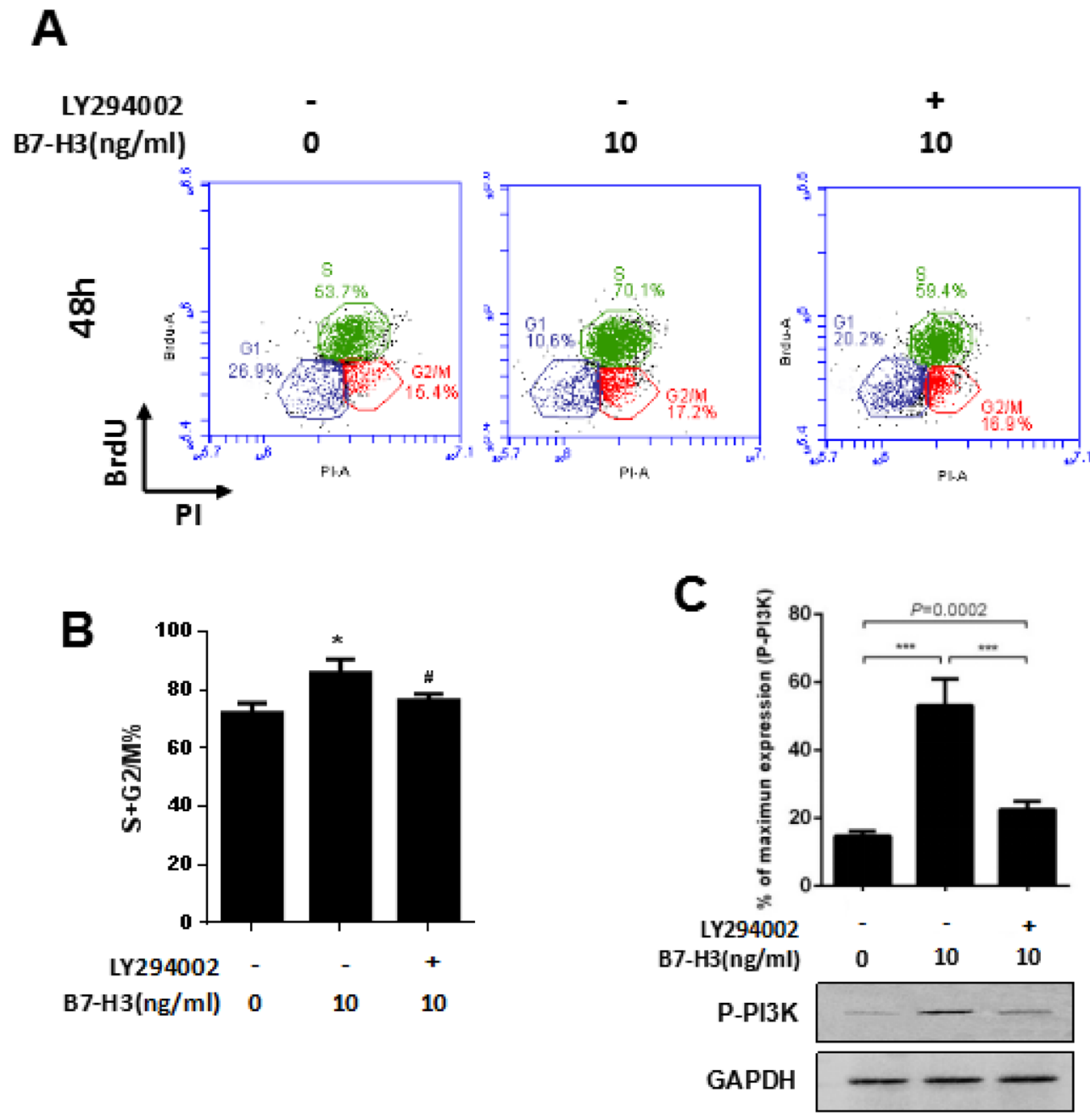

Figure 5: A PI3K inhibitor attenuated the B7-H3-induced cell cycle promotion of SSCs. A. Mouse SSCs were pretreated with $10 \mu \mathrm{M}$ LY294002 before incubation with $10 \mathrm{ng} / \mathrm{ml} \mathrm{B7-H3}$ for $48 \mathrm{~h}$ in vitro, and the cell cycle was assessed by BrdU incorporation. Representative flow cytometry data of three independent experiments are shown. B. The graph represents the percentage of $\mathrm{S}+\mathrm{G} 2 / \mathrm{M}$ shown in $(A)$ in three independent experiments. The results are expressed as the mean \pm standard deviation $(n=3)$. Differences were analyzed by one-way ANOVA followed by Tukey's post hoc analysis. ${ }^{*} P<0.05$ versus no LY294002 inhibition and B7-H3 stimulation. \#P<0.05 versus with B7-H3 stimulation but without LY294002 inhibition. C. Cells treated the same as in $(A)$ were also assessed by western blotting for phosphorylation of PI3K. The lower membrane shows the immunoblotting of phosphorylated PI3K in SSCs. The upper graph shows the quantification of phosphorylated PI3K normalized to the corresponding GAPDH in three independent experiments. The results are expressed as the mean \pm standard deviation $(n=3)$. Differences were analyzed by one-way ANOVA followed by Tukey's post hoc analysis. $* * * P<0.001$. 
decreased in those SSCs treated with both LY294002 and B7-H3 $(76.23 \% \pm 2.20 \%)(P<0.05)$ (Figure 5A and $5 \mathrm{~B})$. Meanwhile, western blot analysis showed that PI3K phosphorylation was successfully inhibited by LY294002, which indicated that PI3K was the pathway involved in the B7-H3-induced cell cycle progression.

\section{DISCUSSION}

In mammals, sperm is produced in the seminiferous tubules of the testis [2], which are composed of seminiferous and interstitial tissues. Sertoli cells, the only sustentacular cells in the interstitial tissues, play a critical role in spermatogenesis by secreting specific substances and direct cell-cell interactions with SSCs. In 2004, Suh et al. [8] first detected B7-H3 expression in mouse testis. Recently, our studies showed that there was a high concentration of soluble B7-H3 in human expressed prostatic secretions [7] as well as in seminal plasma [15]. Additionally, the levels of seminal B7-H3 were associated with sperm counts. Thus, several interesting questions were raised: where B7-H3 localizes in the testis; whether the expression of $\mathrm{B} 7-\mathrm{H} 3$ is associated with sexual maturity; whether this protein influences SSC proliferation and what is the underlying molecular mechanism.

The relative rates of development, maturation and aging in mice and humans are very different. Few published reports have examined the age-specific milestones for mouse sexual maturity. However, Flurkey et al. [28] identified three stages of adult maturation and aging in mice, in which 3-6 months represents the mature adult stage without senescence. Then, the mice enter a middle aged stage from 10 to 15 months. In this stage, degeneration of organs and tissues is initiated. In the current study, we selected $3 \mathrm{w}, 8 \mathrm{w}, 4 \mathrm{~m}$ and $9 \mathrm{~m}$ mice, which represented juvenile, adolescent, mature and middle age stages, respectively. We detected B7-H3 expression in the testis of the $3 \mathrm{w}, 8 \mathrm{w}, 4 \mathrm{~m}$ and $9 \mathrm{~m}$ mice by IHC and western blot. Our data demonstrated that the B7-H3 protein was predominantly localized on the membrane and in the cytoplasm of Sertoli cells but was not expressed on the surface of mouse SSCs (Supplemental Figure 1). The western blot results showed alterations of B7-H3 expression with mouse age. The $4 \mathrm{~m}$ mice had the highest expression of $\mathrm{B} 7-\mathrm{H} 3$, while the $3 \mathrm{w}$ mice had the lowest expression. A decrease in B7-H3 expression was observed in $9 \mathrm{~m}$ mice compared to that of mice in adulthood (4 $\mathrm{m})$. These findings indicated that B7-H3 protein, which is expressed by Sertoli cells, peaked when mice were sexually mature and may play a role in spermatogenesis.

Because SSC proliferation is a critical step in spermatogenesis, we investigated the effect of soluble B7$\mathrm{H} 3$ on the proliferation and cell cycle of mouse SSCs. We isolated SSCs from C57BL/6 mice and measured C-kit and Oct-4 expressions in these cells by flow cytometry. Our results showed that the isolated cells weakly expressed C-kit and strongly expressed Oct-4, which was consistent with previous reports about SSC surface marker expression [1, 29, 30, 32].

The CCK-8 data showed that B7-H3 promotes SSC proliferation in a time- and dose-dependent manner. We also found that B7-H3 promoted cell cycle progression by increasing the percentage of $\mathrm{S}+\mathrm{G} 2 / \mathrm{M}$ phase cells. These results indicated that $\mathrm{B} 7-\mathrm{H} 3$, similar to other substance secreted by or expressed on Sertoli cells, promotes mouse SSC proliferation, which is consistent with our previous findings that the levels of seminal B7-H3 were associated with sperm counts in humans. Although these data suggested that the $\mathrm{B} 7-\mathrm{H} 3$ protein positively affected the proliferation of mouse SSCs, and B7-H3 is predominantly expressed by Sertoli cells in vivo, we investigated whether SSCs were affected by Sertoli cell-derived B7-H3. Then, we co-cultured mouse SSCs with TM4 cells, a Sertoli cell line, in an in vitro transwell system. Our data demonstrated that in the co-culture system, TM4 expressed sufficient levels of B7-H3 to promote the proliferation and cell cycle of mouse SSCs, confirming the important role of Sertoliderived B7-H3 in spermatogenesis.

To further clarify the possible molecular mechanism underlying B7-H3-enhanced SSC proliferation, we investigated three intensively studied signal pathways involved in SSC proliferation [22, 24, 26]. The phosphorylation of PI3K in mouse SSCs was significantly increased after $30 \mathrm{~min}$ of incubation with $10 \mathrm{ng} / \mathrm{ml} \mathrm{B7-}$ $\mathrm{H} 3$ in vitro, while the phosphorylation of ERK and JNK was not increased. Moreover, the B7-H3-induced phosphorylation of $\mathrm{PI} 3 \mathrm{~K}$ reached a plateau, with a saturated concentration of $10 \mathrm{ng} / \mathrm{ml}$. To confirm these results, we added LY294002, a widely used PI3K inhibitor $[33,34]$, to SSCs prior to incubation with B7-H3. As expected, the B7-H3-induced activation of PI3K and the increase in $\mathrm{S}+\mathrm{G} 2 / \mathrm{M}$ cell percentage of SSCs were both attenuated. These data suggested that B7-H3 promoted mouse SSC proliferation via the PI3K pathway.

This study demonstrated for the first time that B7$\mathrm{H} 3$ promoted mouse SSC proliferation through the PI3K pathway, revealing the possible mechanism of B7-H3 in spermatogenesis and identifying $\mathrm{B} 7-\mathrm{H} 3$ as a potential therapeutic agent for human oligozoospermia treatment. However, several limitations of the current study should be noted. First, all the data were generated from mouse testis because it is difficult to obtain testis tissues from healthy humans. Second, although mice have been extensively used in scientific research for decades, few papers have reported the standard for age group determination compared to that of humans. Third, because the biological function of B7-H3 is unknown, only three signaling pathways were selected for analysis in the current study. Although the PI3K pathway was identified as a transducer of B7-H3 signaling in mouse SSCs, the current data are preliminary, and the underlying mechanism requires further analysis. Finally, to confirm the constructive role of 
Sertoli cell-derived B7-H3 in spermatogenesis, selective B7-H3 blocking or a knockdown model should to be studied.

\section{MATERIALS AND METHODS}

\section{Animals and reagents}

C57BL/6 mice were purchased from Xi Nuosai Biotechnology (Suzhou, CHN). Mouse embryonic fibroblasts (MEFs) were obtained from the Cell Bank of the Chinese Academy of Sciences (Shanghai, CHN). Mouse Sertoli cells (TM4) were purchased from Sai Baikang Biotechnology (Shanghai, CHN). Anti-PI3K antibody was obtained from Cell Signaling Technology (Boston, USA). Recombinant mouse B7-H3 was purchased from R\&D Systems (Minneapolis, USA). Antiphospho-PI3K antibody, anti-phospho-ERK1/2 antibody, anti-phospho-JNK1/2/3 antibody, anti-C-kit antibody, antiOct-4 antibody, FITC-conjugated anti-B7-H3 antibody, PE-conjugated goat anti-rat IgG, BRDU, anti-BrdU antibody and Alexa Fluor 488- conjugated goat anti-rat IgG were obtained from Abcam (Cambridge, USA). AntiB7-H3 antibody and goat anti-rabbit IgG antibody were purchased from Lianke Biotechnology (Hangzhou, CHN). FITC-conjugated goat anti-rabbit IgG was purchased from Proteintech Group (Chicago, USA). Recombinant murine LIF and recombinant murine GDNF were purchased from Peprotech Inc. (Rocky Hill, USA). Fetal bovine serum (FBS) and B27 were purchased from Invitrogen (Carlsbad, USA). Phosphate-buffered saline (PBS), high-glucose DMEM and penicillin/streptomycin were obtained from HyClone (Logan, USA). Anti-GAPDH antibody, type IV collagenase, $0.25 \%$ trypsin, insulin, transferrin and Triton X-100 were purchased from Sigma (Saint Louis, USA). Mitomycin C was obtained from Roche (Basel, $\mathrm{CH}$ ). Cell Counting Kit-8 (CCK-8) was purchased from Dojindo Molecular Technologies (Kumamoto, JP). The PI3 kinase inhibitor LY294002 was obtained from Selleck Chemicals (Houston, USA).

\section{Mice and sample preparation}

The protocols for the mouse experiments were approved by the Animal Ethics Committee of Soochow University. For each independent western blot, we obtained the testes from 4 C57BL/6 mice at different ages [3 weeks (w), 8 w, 4 months (m), 9 m]. For each independent immunohistochemistry (IHC) analysis, we obtained the testes from 4 C57BL/6 mice at different ages $(3 \mathrm{w}, 8 \mathrm{w}, 4 \mathrm{~m}, 9 \mathrm{~m})$. Moreover, each experiment was repeated three times. All tissues were collected and weighed using the same method.

\section{IHC analysis}

The testis and epididymis samples were extracted from $\mathrm{C} 57 \mathrm{BL} / 6$ mice. The paraffin- embedded tissues were cut at $4 \mu \mathrm{m}$. Then, each section was dewaxed in xylene at $60^{\circ} \mathrm{C}$ and rehydrated in ethanol solutions. Endogenous peroxidase activity was blocked with $0.3 \% \mathrm{H}_{2} \mathrm{O}_{2}$ solution for $10 \mathrm{~min}$ at room temperature. Next, the sections were incubated in citrate buffer solution at $100^{\circ} \mathrm{C}$ for $30 \mathrm{~min}$ and washed with PBS. The sections were blocked with 5\% BSA for $20 \mathrm{~min}$ at $37^{\circ} \mathrm{C}$ and incubated with anti-B7-H3 antibody (diluted 1:200) overnight at $4{ }^{\circ} \mathrm{C}$. The sections were incubated with horseradish peroxidase-conjugated goat anti-rabbit IgG the next day. Then, the sections were counterstained with hematoxylin.

\section{Western blot}

Each testis was cut into $1 \mathrm{~mm}^{3}$ pieces. Then, they were digested with type IV collagenase for $1 \mathrm{~h}$ at $37^{\circ} \mathrm{C}$. After the tissues were homogenized in PBS, they were incubated with cell lysis buffer containing protease inhibitors on ice for $30 \mathrm{~min}$. The samples were centrifuged at $14,000 \mathrm{X}$ for $10 \mathrm{~min}$ at $4^{\circ} \mathrm{C}$, and the supernatant was collected for western blot analysis. For SSCs, the cells were harvested with $0.25 \%$ trypsin and incubated with cell lysis buffer. The remaining steps were performed as described above. All samples were boiled with $6 \times$ SDSPAGE sample loading buffer for $5 \mathrm{~min}$ at $95^{\circ} \mathrm{C}$.

The proteins were separated using 10\% SDSPAGE and then transferred onto $0.45 \mathrm{~mm}$ polyvinylidene difluoride (PVDF) membranes. After the membranes were blocked in 5\% fat-free milk/0.2\% Tween for $1 \mathrm{~h}$ at room temperature, they were incubated with primary antibodies against B7-H3 (diluted 1:1000), P-PI3K (diluted 1:500), PI3K (diluted 1:1000), P-JNK1/2/3 (diluted 1:5000), P-ERK1/2 (diluted 1:1000), and GAPDH (diluted $1: 1000)$ overnight at $4^{\circ} \mathrm{C}$. The next day, the membranes were incubated with the goat anti-rabbit IgG secondary antibody for $1 \mathrm{~h}$ at room temperature. Then, detection was performed using the BeyoECL Plus substrate system.

\section{Isolation of mouse SSCs}

SSCs were collected from the testes of C57BL/6 mice 7 days after birth by a 2-step enzymatic digestion, according to an existing protocol [35]. Briefly, we first removed the tunica albuginea from the testis to expose the seminiferous tubules. Then, the testes were incubated with $1 \mathrm{mg} / \mathrm{ml}$ type IV collagenase for $15 \mathrm{~min}$ at $37^{\circ} \mathrm{C}$, followed by digestion with $0.25 \%$ trypsin for $10 \mathrm{~min}$ at $37^{\circ} \mathrm{C}$. The testis cells were plated on a gelatin-coated plate overnight, and the floating cells were plated onto other plates. After two to three passages, the cells were transferred onto 
MEFs pretreated with mitomycin $\mathrm{C}$.

\section{Culture of mouse SSCs and TM4}

Mouse SSCs were maintained on mitomycin C-treated MEFs. The basal culture medium was highglucose DMEM supplemented with B27, $25 \mu \mathrm{g} / \mathrm{ml}$ insulin, $100 \mu \mathrm{g} / \mathrm{ml}$ transferrin, $10^{3} \mathrm{U} / \mathrm{ml}$ recombinant murine LIF, $10 \mathrm{ng} / \mathrm{ml}$ recombinant murine GDNF, and 1\% penicillin/streptomycin $[32,36]$. Cells were cultured in an atmosphere of $5 \% \mathrm{CO}_{2}$ at $37^{\circ} \mathrm{C}$. The cells were passaged and split at a 1:2 ratio when they attained $70 \%$ to $80 \%$ confluence. The rest of the cells were discarded. TM4 cells were cultured in high-glucose DMEM in an atmosphere of $5 \% \mathrm{CO}_{2}$ at $37^{\circ} \mathrm{C}$.

\section{Flow cytometry assessment of C-kit and Oct-4 expression in mouse SSCs}

Flow cytometry analysis of C-kit and Oct-4 expression was performed as described previously [37]. Briefly, SSCs were harvested with $0.25 \%$ trypsin and were then resuspended in PBS/FBS. The cells were incubated with an anti-C-kit antibody (diluted 1:100) and anti-Oct-4 antibody (diluted 1:50) for $20 \mathrm{~min}$ at $4^{\circ} \mathrm{C}$.FITC-conjugated goat anti-rabbit IgG (diluted 1:100) and PE-conjugated goat anti-rat $\operatorname{IgG}$ (diluted 1:100) were used as secondary antibodies. The cells were then washed three times with PBS/FBS and analyzed using a FACScan Flow Cytometer (BD Biosciences, NJ). The controls were not treated with primary antibodies.

\section{Transwell co-culture of mouse SSCs and TM4}

Mouse SSCs $\left(1 \times 10^{4}\right)$ were seeded in high-glucose DMEM with supplements in the upper chamber of transwell inserts $(1-\mu \mathrm{m}$ size pore, Corning, Tewksbury, MA) in 24-well plates, and $5 \times 10^{4}$ mitomycin C-pre-treated TM4 cells were seeded in the lower chamber. After coculture for $6,12,24,48$, and 72 hours, the supernatants were collected for B7-H3 quantification, while the SSCs were harvested for proliferation or cell cycle assessments.

\section{Cell proliferation by CCK-8 assay}

CCK- 8 assays were used to determine the effect of B7-H3 on mouse SSC proliferation. Briefly, mouse SSCs plated at 8000 cells per well in triplicates in a 96-well plate were maintained in DMEM supplemented with different concentrations $(0,5,10,25 \mathrm{ng} / \mathrm{ml})$ of recombinant mouse B7-H3 for various times (1, 6, 12, 24, 48, 72 h). At each time point, $10 \mu \mathrm{CCK}-8$ solution was added to each well. Then, the cells were cultured in a humidified atmosphere of $5 \% \mathrm{CO}_{2}$ at $37^{\circ} \mathrm{C}$ for $1 \mathrm{~h}$. Finally, the absorbance of each sample was detected at $450 \mathrm{~nm}$ by a Thermo Multiskan Mk3 microplate reader (Labsystems, Helsinki, Finland).

\section{Cell cycle analysis by BrdU}

For analysis of the role of B7-H3 in mouse SSC growth, SSCs were incubated with different concentrations of B7-H3 $(0,5,10,25 \mathrm{ng} / \mathrm{mL})$ for 48 and $72 \mathrm{~h}$. For analysis of the effects of P-PI3K on mouse SSC proliferation, SSCs were incubated with $10 \mathrm{ng} / \mathrm{ml} \mathrm{B} 7-\mathrm{H} 3$ for 48 and $72 \mathrm{~h}$ after pretreating the cells with $10 \mu \mathrm{M}$ of the inhibitor LY294002 for $6 \mathrm{~h}$; the control groups were incubated with 0 and 10 $\mathrm{ng} / \mathrm{ml} \mathrm{B7-H3}$ for 48 and $72 \mathrm{~h}$. Cells were treated with 10 $\mu \mathrm{M}$ BrdU for $30 \mathrm{~min}$ before collection with $0.25 \%$ trypsin and were then fixed in $70 \%$ ethanol. DNA denaturation was performed by incubation with $2 \mathrm{M} \mathrm{HCl} / 0.5 \%$ Triton $\mathrm{X}-100$ for $30 \mathrm{~min}$ at $37^{\circ} \mathrm{C}$. After the cells were neutralized with $\mathrm{Na}_{2} \mathrm{~B}_{4} \mathrm{O}_{7}$ and washed with PBS, they were incubated with an anti-BrdU antibody (diluted 1:40) for $1 \mathrm{~h}$. Then, the cells were incubated with Alexa Fluor 488-conjugated goat anti-rat $\operatorname{IgG}$ antibody (diluted 1:2000) for $30 \mathrm{~min}$ after centrifugation. Finally, the cells were resuspended with $20 \mu \mathrm{g} / \mathrm{mL}$ propidium iodide to stain the nucleic acids and analyzed by a FACScan Flow Cytometer (BD Biosciences, NJ) [38, 39].

\section{Statistical analysis}

All analyses were performed using GraphPad Prism 6.0, and data are expressed as the mean \pm standard deviation. Statistical differences between groups were determined using one-way ANOVA followed by individual $t$-tests with Tukey's multiple comparison test. Groups with two factors (B7-H3 concentration and incubation time) were analyzed using a two-way ANOVA and Tukey's post test for multiple comparisons. Data were considered statistically significant at $P<0.05$.

\section{Abbreviations}

SSCs: Spermatogonial stem cells; PI3K: Phosphoinositide 3-kinase; IFN- $\gamma$ : Interferon- $\gamma$; VEGF: Vascular endothelial growth factor; ERK: Extracellular signal-regulated kinases; JNK: C-Jun N-terminal kinase; SCF: Stem cell factor; p70S6K: p70 S6 kinase; GDNF: Glial cell line-derived neurotrophic factor; Ras: Rat sarcoma; MAPK: Mitogen-activated protein kinase; MEK: MAPK/ERK kinase; ROS: Reactive oxygen species; IHC: Immunohistochemistry; PVDF: Polyvinylidene difluoride

\section{Author contributions}

XW and KL designed the study, performed the experiments and data analysis, and drafted the manuscript. 
$\mathrm{GZ}, \mathrm{YH}$ and JL contributed to the design of the study, experiments, and data analysis. ML, LZ, CF and JP contributed to the experiments. JH and HY conceived of and designed the study and supervised the work. All authors read and approved the final manuscript.

\section{CONFLICTS OF INTEREST}

The authors declare that they have no relevant conflict of interest.

\section{FUNDING}

This work was supported by the National Natural Science Foundation of China (81300537), the Key Discipline of Medicine of Jiangsu Province (ZDXKA2016012), and the Key Discipline of Reproductive Medicine and Science and Technology Program of Suzhou (LCXZ201302, H201311, SYS201453, SYS201754 and LCZX201502).

\section{REFERENCES}

1. Kubota H, Avarbock MR, Brinster RL. Spermatogonial stem cells share some, but not all, phenotypic and functional characteristics with other stem cells. Proc Natl Acad Sci U S A. 2003; 100: 6487-6492.

2. Li N, Mruk DD, Tang EI, Lee WM, Wong CK, Cheng CY. Formin 1 regulates microtubule and F-Actin organization to support spermatid transport during spermatogenesis in the rat testis. Endocrinology. 2016; 157: 2894-2908.

3. Kanatsu-Shinohara M, Shinohara T. Spermatogonial stem cell self-renewal and development. Annu Rev Cell Dev Biol. 2013; 29: 163-187.

4. Chen SR, Liu YX. Regulation of spermatogonial stem cell self-renewal and spermatocyte meiosis by Sertoli cell signaling. Reproduction. 2015; 149: R159-R167.

5. Chapoval AI, Ni J, Lau JS, Wilcox RA, Flies DB, Liu D, Dong H, Sica GL, Zhu G, Tamada K, Chen L. B7-H3: a costimulatory molecule for $\mathrm{T}$ cell activation and IFNgamma production. Nat Immunol. 2001; 2: 269-274.

6. Zhang G, Hou J, Shi J, Yu G, Lu B, Zhang X. Soluble CD276 (B7-H3) is released from monocytes, dendritic cells and activated $\mathrm{T}$ cells and is detectable in normal human serum. Immunology. 2008; 123: 538-546.

7. Wei X, Zhang G, Yuan H, Ding X, Li S, Zhang X, Hou J. Detection and quantitation of soluble B7-H3 in expressed prostatic secretions: a novel marker in patients with chronic prostatitis. J Urol. 2011; 185: 532-537.

8. Suh WK, Wang SX, Jheon AH, Moreno L, Yoshinaga SK, Ganss B, Sodek J, Grynpas MD, Mak TW. The immune regulatory protein $\mathrm{B} 7-\mathrm{H} 3$ promotes osteoblast differentiation and bone mineralization. Proc Natl Acad Sci U S A. 2004; 101: 12969-12973.
9. Ling V, Wu PW, Spaulding V, Kieleczawa J, Luxenberg D, Carreno BM, Collins M. Duplication of primate and rodent B7-H3 immunoglobulin V- and C-like domains: divergent history of functional redundancy and exon loss. Genomics. 2003; 82: 365-377.

10. Suh WK, Gajewska BU, Okada H, Gronski MA, Bertram EM, Dawicki W, Duncan GS, Bukczynski J, Plyte S, Elia A, Wakeham A, Itie A, Chung S, et al. The B7 family member B7-H3 preferentially down-regulates T helper type 1-mediated immune responses. Nat Immunol. 2003; 4: 899906.

11. Prasad DV, Nguyen T, Li Z, Yang Y, Duong J, Wang Y, Dong C. Murine B7-H3 is a negative regulator of T cells. J Immunol. 2004; 173: 2500-2506.

12. Fukushima A, Sumi T, Fukuda K, Kumagai N, Nishida T, Yamazaki T, Akiba H, Okumura K, Yagita H, Ueno H. B7-H3 regulates the development of experimental allergic conjunctivitis in mice. Immunol Lett. 2007; 113: 52-57.

13. Sun J, Guo YD, Li XN, Zhang YQ, Gu L, Wu PP, Bai GH, Xiao Y. B7-H3 expression in breast cancer and upregulation of VEGF through gene silence. OncoTargets Ther. 2014; 7 : 1979-1986

14. Xu L, Zhang G, Zhou Y, Chen Y, Xu W, Wu S, Zhang X. Stimulation of B7-H3 (CD276) directs the differentiation of human marrow stromal cells to osteoblasts. Immunobiology. 2011; 216: 1311-1317.

15. Wei X, Li Z, Zhang G, Yuan H, Lv J, Jiang Y, Zhang W, Huang Y, Hou J. B7-H3 promoted sperm motility in humans. Urology. 2014; 83: 324-330.

16. Wong $\mathrm{CH}$, Cheng CY. Mitogen-activated protein kinases, adherens junction dynamics, and spermatogenesis: a review of recent data. Dev Biol. 2005; 286: 1-15.

17. Walker WH. Non-classical actions of testosterone and spermatogenesis. Philos Trans R Soc Lond B Biol Sci. 2010; 365: 1557-1569.

18. Carreau S, Bois C, Zanatta L, Silva FR, Bouraima-Lelong $\mathrm{H}$, Delalande C. Estrogen signaling in testicular cells. Life Sci. 2011; 89: 584-587.

19. Ickowicz D, Finkelstein M, Breitbart H. Mechanism of sperm capacitation and the acrosome reaction: role of protein kinases. Asian J Androl. 2012; 14: 816-821.

20. Walker EH, Perisic O, Ried C, Stephens L, Williams RL. Structural insights into phosphoinositide 3-kinase catalysis and signalling. Nature. 1999; 402: 313-320.

21. Naguib A. Following the trail of lipids: signals initiated by PI3K function at multiple cellular membranes. Sci Signal. 2016; 9: re4

22. Feng LX, Ravindranath N, Dym M. Stem cell factor/c-kit up-regulates cyclin D3 and promotes cell cycle progression via the phosphoinositide 3-kinase/p70 S6 kinase pathway in spermatogonia. J Biol Chem. 2000; 275: 25572-25576.

23. Sagare-Patil V, Vernekar M, Galvankar M, Modi D. Progesterone utilizes the PI3K-AKT pathway in human spermatozoa to regulate motility and hyperactivation but 
not acrosome reaction. Mol Cell Endocrinol. 2013; 374: $82-91$.

24. He Z, Jiang J, Kokkinaki M, Golestaneh N, Hofmann MC, Dym M. Gdnf upregulates c-Fos transcription via the Ras/ Erk1/2 pathway to promote mouse spermatogonial stem cell proliferation. Stem Cells. 2008; 26: 266-278.

25. Hasegawa K, Namekawa SH, Saga Y. MEK/ERK signaling directly and indirectly contributes to the cyclical selfrenewal of spermatogonial stem cells. Stem Cells. 2013; 31: 2517-2527.

26. Morimoto $\mathrm{H}$, Iwata $\mathrm{K}$, Ogonuki $\mathrm{N}$, Inoue $\mathrm{K}$, Atsuo $\mathrm{O}$, Kanatsu-Shinohara M, Morimoto T, Yabe-Nishimura C, Shinohara T. ROS are required for mouse spermatogonial stem cell self-renewal. Cell Stem Cell. 2013; 12: 774-786.

27. García BM, Moran AM, Fernandez LG, Ferrusola CO, Rodriguez AM, Bolanos JM, da Silva CM, Martinez HR, Tapia JA, Pena FJ. The mitochondria of stallion spermatozoa are more sensitive than the plasmalemma to osmotic-induced stress: role of c-Jun N-terminal kinase (JNK) pathway. J Androl. 2012; 33: 105-113.

28. Flurkey K, Currer JM, Harrison DE. Mouse Models in Aging Research. The Mouse in Biomedical Research (Second Edition). History, Wild Mice, and Genetics. 2007; 3: 637-72. https://doi.org/10.1016/B978-0123694546/50074-1.

29. Yoshinaga K, Nishikawa S, Ogawa M, Hayashi S, Kunisada T, Fujimoto T, Nishikawa S. Role of c-kit in mouse spermatogenesis: identification of spermatogonia as a specific site of c-kit expression and function. Development. 1991; 113: 689-699.

30. Pesce M, Schöler HR. Oct-4: gatekeeper in the beginnings of mammalian development. Stem Cells. 2001; 19: 271278.

31. Ohbo K, Yoshida S, Ohmura M, Ohneda O, Ogawa T, Tsuchiya H, Kuwana T, Kehler J, Abe K, Scholer HR, Suda T. Identification and characterization of stem cells in prepubertal spermatogenesis in mice. Dev Biol. 2003; 258: 209-225.

32. Kanatsu-Shinohara $\mathrm{M}$, Miki H, Inoue $\mathrm{K}$, Ogonuki N, Toyokuni S, Ogura A, Shinohara T. Long-term culture of mouse male germline stem cells under serum-or feeder-free conditions. Biol Reprod. 2005; 72: 985-991.

33. Huang $\mathrm{YH}$, Chin CC, Ho HN, Chou CK, Shen CN, Kuo HC, Wu TJ, Wu YC, Hung YC, Chang CC, Ling TY. Pluripotency of mouse spermatogonial stem cells maintained by IGF-1- dependent pathway. FASEB J. 2009; 23: 2076-2087.

34. Xu H, Shen L, Chen X, Ding Y, He J, Zhu J, Wang Y, Liu X. mTOR/P70S6K promotes spermatogonia proliferation and spermatogenesis in Sprague Dawley rats. Reprod Biomed Online. 2016; 32: 207-217.

35. Ogawa T, Arechaga JM, Avarbock MR, Brinster RL. Transplantation of testis germinal cells into mouse seminiferous tubules. Int J Dev Biol. 1997; 41: 111-122.
36. Wu Z, Falciatori I, Molyneux LA, Richardson TE, Chapman KM, Hamra FK. Spermatogonial culture medium: an effective and efficient nutrient mixture for culturing rat spermatogonial stem cells. Biol Reprod. 2009; 81: 77-86.

37. Shinohara T, Avarbock MR, Brinster RL. beta1- and alpha6integrin are surface markers on mouse spermatogonial stem cells. Proc Natl Acad Sci U S A. 1999; 96: 5504-5509.

38. Kranz D, Dohmesen C, Dobbelstein M. BRCA1 and Tip60 determine the cellular response to ultraviolet irradiation through distinct pathways. J Cell Biol. 2008; 182: 197-213.

39. Wang AT, Sengerova B, Cattell E, Inagawa T, Hartley JM, Kiakos K, Burgess-Brown NA, Swift LP, Enzlin JH, Schofield CJ, Gileadi O, Hartley JA, McHugh PJ. Human SNM1A and XPF-ERCC1 collaborate to initiate DNA interstrand cross-link repair. Genes Dev. 2011; 25: 18591870 . 